\title{
SB431542 inhibited cigarette smoke extract induced invasiveness of A549 cells via the TGF-ß31/Smad2/MMP3 pathway
}

\author{
KE LIAO, CHEN-WEI YONG and KE HUA \\ Department of Respiration and Gastroenterology, The Seventh Peoples Hospital of Chengdu, \\ Chengdu, Sichuan 610000, P.R. China
}

Received August 27, 2017; Accepted February 19, 2018

DOI: $10.3892 / \mathrm{ol} .2018 .8556$

\begin{abstract}
Lung cancer has high morbidity and mortality rates. Smoking is involved in the pathogenesis of lung cancer, and tobacco smoke may increase tumor cell invasion and metastasis. The effects of cigarette smoke extract (CSE) on the carcinoma human alveolar basal epithelial A549 cell line were investigated. A549 cells were exposed to increasing concentrations of CSE for 12, 24 and $48 \mathrm{~h}$, and the transforming growth factor- $\beta 1$ (TGF- $\beta 1$ ) signal pathway was inhibited by addition of SB431542, a TGF- $\beta 1$ receptor antagonist. The proliferation of A549 cells was assayed by a Cell Counting kit-8, invasiveness was assayed using Transwell chambers, and TGF- $\beta 1$, phosphorylated mothers against decapentaplegic homolog 2 (p-Smad2), and matrix metalloproteinase 3 (MMP3) levels was assessed by western blot analysis. The invasiveness of A549 cells and the expression of TGF- $\beta 1, \mathrm{pSmad} 2$, and MMP-3 were significantly increased by CSE $(\mathrm{P}<0.05)$. The effects of CSE were abrogated by SB431542 ( $\mathrm{P}<0.05)$. In conclusion, CSE increased the invasiveness of A549 cells and its effects were abrogated by SB431542 and the TGF- $\beta 1 /$ Smad2/MMP-3 pathway may have been involved.
\end{abstract}

\section{Introduction}

Smoking is the primary cause of lung cancer. The proportion of cases attributable to smoking has reached $90 \%$ in countries with ongoing high tobacco consumption (1). Cigarette smoke contains at least 69 carcinogens, including ammonia, cadmium, nickel, nicotine (2), and nitrosamines such as 4-(methyln itrosamino)-1-(3-pyridyl)-1-butanone (3). Tobacco smoke components not only cause cancer, but may also be involved in tumor invasiveness and metastasis. Cigarette smoking is

Correspondence to: Dr Ke Liao, Department of Respiration and Gastroenterology, The Seventh Peoples Hospital of Chengdu, 1 Zhiming Road, Chengdu, Sichuan 610000, P.R. China

E-mail:cqmuliao@sina.com

Key words: cigarette smoke extract, A549 cells, SB431542, transforming growth factor- $\beta 1$, mothers against decapentaplegic homolog 2, matrix metalloproteinase 3 known to increase the risk of prostate cancer metastasis (4), the metastatic ability of breast cancer cells (5), and the risk of pulmonary metastasis of breast cancer (6). Tobacco smoke may also increase the spread of lung carcinoma cells (7); however, the mechanism by which this happens is, to the best of our knowledge, unclear.

Metastasis is a well-regulated process (8) that depends on the invasion of cancer cells into surrounding tissues; it is a leading cause of cancer mortality (9), and is characteristic of lung cancer. Transforming growth factor- $\beta$ (TGF- $\beta$ ) may be a key regulator of tumor cell invasion and metastasis. TGF- $\beta 1$, TGF- $\beta 2$ and TGF- $\beta 3$ are members of a superfamily of secreted cytokines that regulate cellular processes, including proliferation, differentiation, migration, survival, and immunity, by ligand-receptor binding (10-12). TGF- $\beta$ family members are ubiquitously expressed. The TGF- $\beta 1$-induced epithelial-mesenchymal transition in lung cancer is a key first step in metastasis (13), and exposure of A549 cells to cigarette smoke extract (CSE) induces the expression, release and activation of TGF- $\beta 1$ (14).

Matrix metalloproteinase (MMP) activity in tumor cell metastasis includes degrading of basement membranes and the extracellular matrix, which facilitates tumor invasion and metastasis $(15,16)$. TGF- $\beta 1$ has been reported to stimulate the expression of matrix metalloproteinase 3 (MMP3) in human corneal epithelial cells (17), but it is not known whether it has similar activity in lung cancer cells. The present study investigated the effect of CSE on the invasiveness of A549 cells and the possible involvement of TGF- $\beta$. The proliferation and invasiveness of A549 cells increased following CSE exposure. Expression of TGF- $\beta 1$, mothers against decapentaplegic homolog 2 (Smad2), and MMP3 was significantly increased by CSE and partly abrogated by SB431542, a TGF- $\beta 1$ receptor inhibitor. SB431542 inhibited the CSE-induced invasiveness of A549 cells via the TGF- $\beta 1 /$ MMP3 pathway.

\section{Materials and methods}

Cell culture and reagents. The A549 cell line was purchased from the American Type Culture Collection (Manassas, VA, USA) and cultured in Dulbecco's Modified Eagle's Medium (DMEM) (Thermo Fisher Scientific, Inc., Waltham, MA, USA) containing $10 \%$ fetal bovine serum (FBS) (Thermo Fisher Scientific, Inc.) at $37^{\circ} \mathrm{C}$ in a humidified $5 \% \mathrm{CO}_{2}$ atmosphere. 
The Cell Counting kit-8 (CCK-8) kit was obtained from Dojindo Molecular Technologies Inc. (Kumamoto, Japan). GAPDH, TGF- $\beta 1$, phosphorylated (p)-Smad2, and MMP3 primary antibodies (dilution 1:1,000) were obtained from Abcam (Cambridge, MA, USA). Solid SB431542 (cat. no. HY-10431) was obtained from MedChemExpress (Monmouth Junction, NJ, USA). The SB431542 was dissolved in $1 \mathrm{ml} \mathrm{DMEM} \mathrm{and}$ the concentration was adjusted to of $10 \mathrm{mmol} / \mathrm{l}$, which was verified to have no effect on the cell proliferation in preliminary experiments.

CSE preparation. Research cigarettes were purchased from Chengdu Tobacco Industry Co., Ltd. (Chengdu, China); when burned, each cigarette contained $11 \mathrm{mg}$ tar, $17 \mathrm{mg}$ carbon monoxide, and $1.1 \mathrm{mg}$ nicotine. CSE was prepared as described by Wirtz and Schmidt (18). Briefly, the filters were removed, cigarettes were installed on a pumping apparatus, and completely combusted in $2 \mathrm{~min}$. The smoke from ten cigarettes was bubbled through a glass vessel containing $10 \mathrm{ml}$ of serum-free DMEM, which was then adjusted to $\mathrm{pH} 7.4$ and filtered through a $0.22-\mu \mathrm{m}$ filter (EMD Millipore, Billerica, MA, USA) to remove particles and bacteria. The CSE was standardized by measuring the absorbance at a wavelength of $320 \mathrm{~nm}$ with a DU 640 spectrophotometer (Beckman Coulter, Inc., Brea, CA, USA). DMEM was used as the blank control. The CSE spectrogram exhibited little variance $(1.36 \pm 0.12 \mathrm{mmol} / \mathrm{l})$ across preparations. The concentration of the resulting solution was designated as $100 \%$ and was diluted as required $(0.1,1.0$ and $10.0 \%)$ for use in the experimental procedures. The CSE solutions were freshly prepared, and used within $30 \mathrm{~min}$ of preparation.

Cell Counting kit-8 (CCK-8) proliferation assay. In brief, A549 cells were treated with CSE, then seeded into 96-well plates at a density of $5 \times 10^{4}$ cells/well in $100 \mu 1$ DMEM and incubated at $37^{\circ} \mathrm{C}$. When the cells reached $70 \%$ confluence, the medium was replaced with an equal volume containing CSE at concentrations of $0.1,1.0$ and $10.0 \%$ and cultured for 12, 24, or $48 \mathrm{~h}$ before addition of $10 \mu \mathrm{l}$ CCK- 8 solution. After $1-2 \mathrm{~h}$, absorbance was read at $490 \mathrm{nM}$ using a microplate reader (BioTek Instruments, Inc., Winooski, VT, USA).

Cell motility assay. The invasiveness of A549 cells was assayed in BioCoat Matrigel-coated invasion chambers (BD Biosciences, Franklin Lakes, NJ, USA) with 8- $\mu$ m-pore size polycarbonate membranes. Cells were grown in serum-free DMEM at $37^{\circ} \mathrm{C}$ for $2 \mathrm{~h}$, the medium was removed and $750 \mu \mathrm{l}$ DMEM with $10 \%$ FBS was added into the lower chamber as a chemoattractant. A549 cells were treated with CSE or SB431542, then added to each upper chamber at a density of $5 \times 10^{4}$ cells/well in $2 \mathrm{ml}$ DMEM with $1 \% \mathrm{FBS}$. After $2 \mathrm{~h}, 1.0 \% \mathrm{CSE}$ and $100 \mathrm{nmol} / \mathrm{l} \mathrm{SB} 431542$ were added to the upper chambers. The inserts and non-invasive cells were removed after $12 \mathrm{~h}$. The invasive cells on the lower surface of the membrane were then fixed in $100 \%$ methanol for $15 \mathrm{~min}$ at room temperature, air dried, and stained with crystal violet for $30 \mathrm{~min}$ at room temperature. The numbers of cell in five random visual fields with a fluorescence microscope (Olympus Corporation, Tokyo, Japan) at a magnification of x200 were recorded.
Western blot assays. Cells were treated with CSE or SB431542, then separated by $1 \mathrm{ml} 0.25 \%$ trypsin (Thermo Fisher Scientific, Inc.), then disrupted in ice-cold lysis buffer containing protease and phosphatase inhibitors (cat. no. FNN0011; Thermo Fisher Scientific, Inc.) for $30 \mathrm{~min}$, and then clarified by centrifugation at 2,000 $\mathrm{x} \mathrm{g}$ for $10 \mathrm{~min}$ at $4^{\circ} \mathrm{C}$. Total protein concentration was determined using a bicinchoninic acid assay, and the sample was boiled for $5 \mathrm{~min}$ before loading. The cell lysate was resuspended in SDS buffer (Beyotime Institute of Biotechnology, Haimen, China), and $40 \mu \mathrm{g}$ samples of protein were separated by 8\% SDS-PAGE (Beyotime Institute of Biotechnology). The proteins were transferred to polyvinylidene difluoride membranes (EMD Millipore), blocked for $2 \mathrm{~h}$ with $5 \%$ bovine serum albumin (Beyotime Institute of Biotechnology) incubated with primary antibodies: Antibodies of GAPDH (cat. no. ab8245; dilution 1:1,000); TGF- $\beta 1$ (cat. no. ab92486; dilution 1:1,000); phosphorylated (p)-Smad2 (cat. no. ab40855; dilution 1:1,000); and MMP3 (cat. no. ab53015; dilution 1:1,000) were obtained from Abcam. The incubation was overnight at $4^{\circ} \mathrm{C}$, and then incubated with the corresponding horseradish peroxidase-conjugated secondary antibody (cat. no. HP6023; dilution 1:1,000; Abcam) for $2 \mathrm{~h}$ at $20^{\circ} \mathrm{C}$. Immunoreactivity was visualized by SuperEnhanced chemiluminescence kit (Millipore, Bedford, MA, USA) and the results were analyzed by Quantity One software v4.4.02 (Bio-Rad Laboratories, Inc., Hercules, CA, USA).

Statistical analysis. Experimental procedures were performed in triplicate, and the results were expressed as the mean \pm standard deviation. The significance of differences between the CSE groups was assessed by one-way analysis of variance followed by Dunnett's test. Student's t-test was used to compare the differences in different treatment groups. Statistical analysis was performed with GraphPad Prism version 5.01 (GraphPad Software, Inc., La Jolla, CA, USA). $\mathrm{P}<0.05$ was considered to indicated statistically significant difference.

\section{Results}

CSE treatment increases the invasiveness of A549 cells. The proliferation and invasiveness of A549 cells were assayed following CSE treatment at concentrations of 0.1, 1.0, and $10.0 \%$ for 12,24 , and $48 \mathrm{~h}$ (Fig. 1A). At a concentration of $10.0 \%$, CSE significantly decreased the proliferation of A549 cell; however, proliferation was not significantly affected by $1.0 \% \mathrm{CSE}$. Therefore, the effect of CSE on invasiveness was evaluated at a concentration of $1.0 \%$. The results of the Transwell invasion assay (Fig. 1B) revealed that there were significantly more invasive cells on the lower membrane surface following CSE treatment compared with control cultures $(\mathrm{P}<0.05)$.

CSE exposure significantly increases TGF- $\beta 1$, Smad2, and MMP3 expression in A549 cells. To determine whether CSE promoted the activation of the TGF- $\beta 1$ pathway, A549 cells were treated with $1.0 \% \mathrm{CSE}$ for $48 \mathrm{~h}$, and the expression of TGF- $\beta 1$ and Smad2, which mediates TGF- $\beta 1$ signaling, was assessed. The expression levels of TGF- $\beta 1$ and Smad2 were significantly increased following CSE exposure 

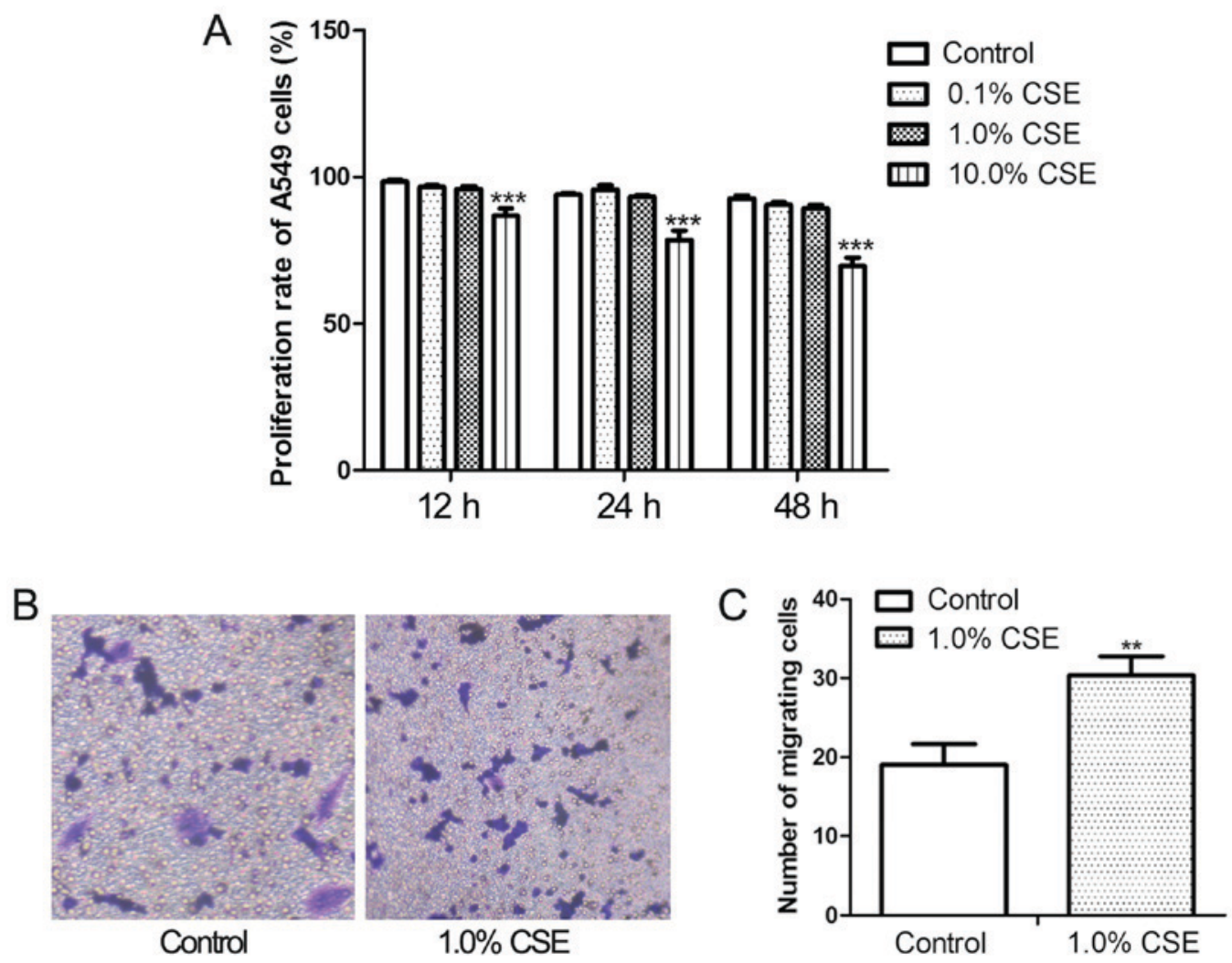

Figure 1. CSE increases the invasiveness of A549 cells. (A) Cells were exposed to CSE at concentrations of 0.1-10.0\% for 12, 24, or $48 \mathrm{~h}$ and the effect on cell viability was determined by Cell Counting kit-8 assay. (B) A549 cells were treated with $1.0 \%$ CSE for $12 \mathrm{~h}$, and the effect on invasiveness was determined by Transwell assay and (C) quantified. ${ }^{* *} \mathrm{P}<0.01$ and ${ }^{* * *} \mathrm{P}<0.001$ vs. controls. CSE, cigarette smoke extract.

(Fig. 2A and B). The expression of MMP3, an indicator of metastasis, was also significantly increased in A549 cells following exposure to CSE (Fig. 2C and D).

Increased TGF- $\beta 1$, Smad2, MMP3 expression and cell invasiveness in response to CSE is partly inhibited by SB431542. A549 cells were exposed to SB431542, a TGF- $\beta 1$ receptor antagonist, to assess the involvement of TGF- $\beta 1 /$ Smad2, and MMP3 following CSE treatment. At a density of $10 \mathrm{mmol} / \mathrm{l}$, which was verified to have no effect on the cell proliferation in preliminary experiments (data not shown), to block the TGF- $\beta 1$ receptor, SB431542 significantly decreased TGF- $\beta 1$, Smad 2 and MMP3 expression (Fig. $3 \mathrm{~A}$ and B). In the Transwell invasion assay, SB431542 inhibited the effect of CSE on the invasiveness of A549 cells. The number of invasive CSE-exposed A549 cells was significantly decreased by treatment with SB431542 (Fig. 3C and D).

\section{Discussion}

CSE exposure increased the proliferation and invasiveness of A549 cells; it also increased MMP3 production and TGF- $\beta 1 /$ Smad2 pathway activity, which were inhibited by SB431542, a known TGF- $\beta 1$ receptor antagonist.

The smoke generated from the tobacco in cigarettes exposes the smoker to upwards of 4,000 different xenobiotic chemicals $(19,20)$, and exposure to cigarette smoke increases the risk of lung cancer (21). Cigarette smoke has also been associated with pancreatic cancer metastasis (22) and with the increased metastatic ability of breast cancer cells via promotion of the epithelial-mesenchymal transition (5). CSE has also been reported to enhance the metastatic ability and invasiveness of lung cancer cells (7). In the present study CSE increased the invasiveness of A549 cells (Fig. 1B and C).

Metastasis is a complex multistep process and a leading cause of cancer-associated mortality (9). MMP3 is a proteolytic enzyme that is active in metastasis, capable of degrading structural components of the extracellular matrix (23) and disrupting intercellular and cell-extracellular matrix adhesions (24). MMP3 activity contributes to tumor invasion and metastasis, and is indicative of a poor survival prognosis (25). CSE exposure increased the expression of MMP3 in A549 cells (Fig. 2C and D) and may have increased the invasiveness of lung cancer cells by upregulating the MMP3 expression, which is in line with previous reports of MMP3 activity in lung cancer metastasis (26). As there are several other MMPs involved in the cancer metastasis, their roles should be studied in future experiments.

TGF- $\beta$ is a mediator of cancer invasion and metastasis (27). TGF- $\beta$ signals are transferred to the nucleus via TGF- $\beta$ type I or type II receptors that phosphorylate canonical Smad2/3 downstream effectors (28). In the present study, CSE increased TGF- $\beta 1$ and Smad 2 activity (Fig. $2 \mathrm{~A}$ and B). In vitro, treatment with an anti-MMP3 antibody was found to result in a dose-dependent decrease in active TGF- $\beta 1$ (27). Activated TGF- $\beta$ can regulate the secretion, expression, and activation of MMP3, resulting in a bidirectional regulatory loop (29). 

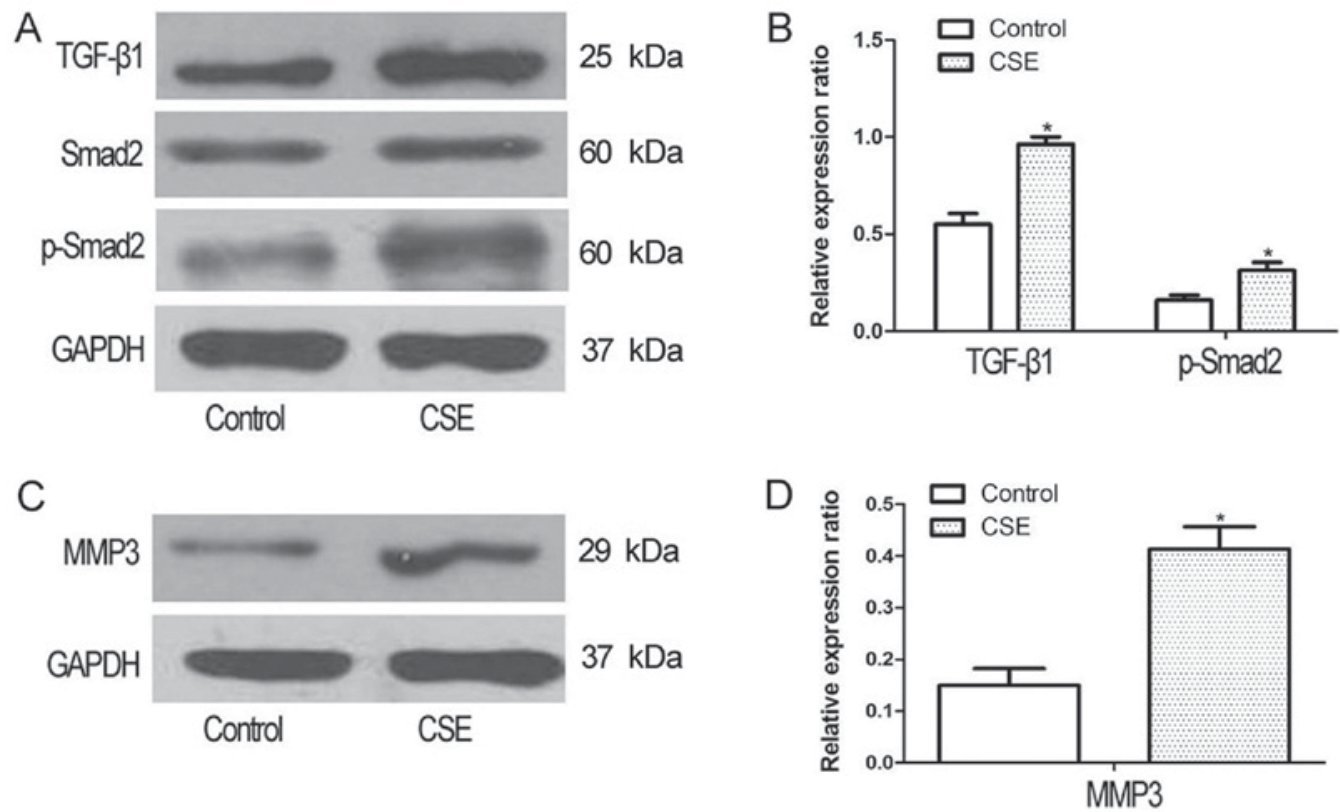

Figure 2. Levels of TGF- $\beta 1$, p-Smad2, and MMP3 in A549 cells was assayed by western blotting following CSE exposure for $48 \mathrm{~h}$. (A) Western blot analysis reveals that levels of TGF- $\beta 1$ and p-Smad2 were increased following exposure to 1.0\% CSE exposure, with (B) densitometry analysis confirming this. (C) MMP3 expression in in 549 cells was significantly increased following exposure to $1.0 \%$ CSE, with (D) densitometry analysis confirming this. "P $<0.05$ vs. controls CSE, cigarette smoke extract; TGF- $\beta 1$, transforming growth factor- $\beta 1$; -Smad2, phosphorylated mothers against decapentaplegic homolog 2 ; MMP3, matrix metalloproteinase 3 .
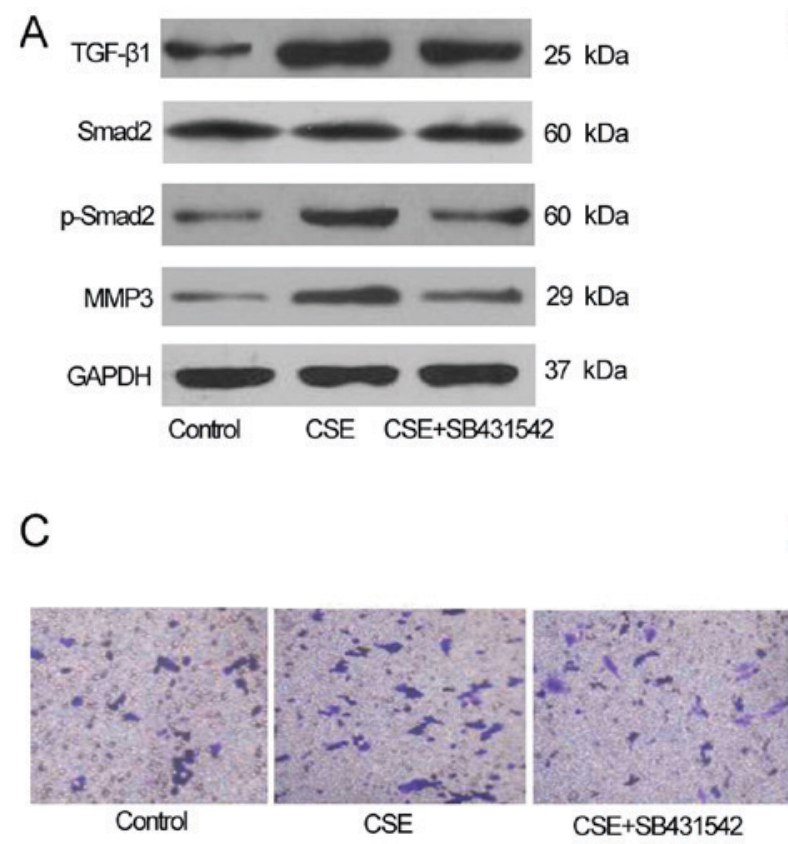
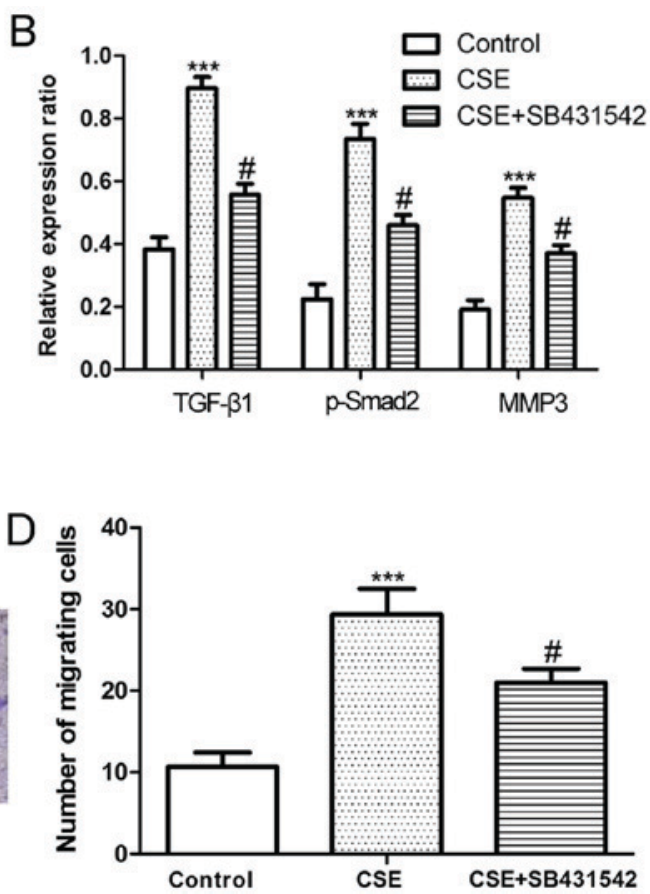

Figure 3. Levels of TGF- $\beta 1$, p-Smad2, and MMP3 increased by CSE treatment in A549 cells was significantly inhibited by SB431542. (A) A549 cells were treated with $1.0 \%$ CSE with or without $10.0 \mathrm{mmol} / 1 \mathrm{SB} 431542$ for $48 \mathrm{~h}$, the levels of TGF- $\beta 1$, p-Smad2, and MMP3 was assayed by western blot analysis, with (B) densitometry analysis confirming this. (C) The invasiveness of A549 cells was determined by Transwell assays and (D) quantified. ${ }^{* * *} \mathrm{P}<0.001 \mathrm{vs}$. control; ${ }^{\#} \mathrm{P}<0.05$, CSE+SB431542 vs. CSE only. CSE, cigarette smoke extract; TGF- $\beta 1$, transforming growth factor- $\beta 1$; $p$-Smad2, phosphorylated mothers against decapentaplegic homolog 2; MMP3, matrix metalloproteinase 3 .

SB431542 is a TGF- $\beta 1$ receptor kinase inhibitor that interrupts the activation of downstream signaling pathways (30). SB431542 has previously been reported by Tanaka et al (31) to induce an in vivo antitumor immune response associated with TGF- $\beta$ activity. Matsuyama et al (32) reported that SB431542 exerted antitumor activity by inhibiting the proliferation of osteosarcoma cells. Xi et al (33) revealed that SB431542 inhibited the invasiveness of RPMI 8226 cells by decreasing the expression of MMP3. In the present study, SB431542 significantly inhibited the activity 
of the TGF $\beta 1 / \mathrm{Smad} 2$ pathway and decreased MMP3 expression in A549 cells exposed to CSE (Fig. 3A and B), and reduced the invasiveness of CSE-treated A549 cells (Fig. 3C and D).

In the current study, the promotion of the invasiveness of lung cancer cells by CSE was associated with the activation of the TGF $31 / \mathrm{Smad} 2$ pathway and regulation of MMP3 expression. The effects of CSE were partially reversed by SB431542, a TGF $\beta 1$ receptor antagonist that may have therapeutic potential in cancer, which could be proven in other in vitro models, such as HAC-84 and GLC-15 cells, or in vivo experiments in the future.

\section{Acknowledgements}

Not applicable.

\section{Funding}

No funding was received.

\section{Availability of data and materials}

All the data and materials are available upon reasonable request.

\section{Authors' contributions}

KL contributed to the study design and contributed to data analysis, $\mathrm{CY}$ contributed to performing experiments and $\mathrm{KH}$ contributed to data analysis.

\section{Ethics approval and consent to publish}

Not applicable.

\section{Consent for publication}

Not applicable.

\section{Competing interests}

The authors declare that they have no competing interests.

\section{References}

1. Pesch B, Kendzia B, Gustavsson P, Jöckel KH, Johnen G, Pohlabeln H, Olsson A, Ahrens W, Gross IM, Brüske I, et al: Cigarette smoking and lung cancer--relative risk estimates for the major histological types from a pooled analysis of case-control studies. Int J Cancer 131: 1210-1219, 1012.

2. Song MA, Marian C, Brasky TM, Reisinger S, Djordjevic M and Shields PG: Chemical and toxicological characteristics of conventional and low-TSNA moist snuff tobacco products. Toxicol Lett 245: 68-77, 2016.

3. Hecht SS: It is time to regulate carcinogenic tobacco-specific nitrosamines in cigarette tobacco. Cancer Prev Res (Phila) 7: 639-647, 2014.

4. Moreira DM, Aronson WJ, Terris MK, Kane CJ, Amling CL, Cooperberg MR, Boffetta P and Freedland SJ: Cigarette smoking is associated with an increased risk of biochemical disease recurrence, metastasis, castration-resistant prostate cancer, and mortality after radical prostatectomy: Results from the SEARCH database. Cancer 120: 197-204, 2014.
5. Di Cello F, Flowers VL, Li H, Vecchio-Pagán B, Gordon B, Harbom K, Shin J, Beaty R, Wang W, Brayton C, et al: Cigarette smoke induces epithelial to mesenchymal transition and increases the metastatic ability of breast cancer cells. Mol Cancer 12: 90, 2013.

6. Murin S and Inciardi J: Cigarette smoking and the risk of pulmonary metastasis from breast cancer. Chest 119: 1635-1640, 2001.

7. Gopalakrishna R, Chen ZH and Gundimeda U: Tobacco smoke tumor promoters, catechol and hydroquinone, induce oxidative regulation of protein kinase $\mathrm{C}$ and influence invasion and metastasis of lung carcinoma cells. Proc Natl Acad Sci USA 91: 12233-12237, 1994.

8. Li Y, Li Y, Liu J, Fan Y, Li X, Dong M, Liu H and Chen J: Expression levels of microRNA-145 and microRNA-10b are associated with metastasis in non-small cell lung cancer. Cancer Biol The 17: 272-279, 2016.

9. Gupta GP and Massagué J: Cancer metastasis: Building a framework. Cell 127: 679-695, 2006.

10. Imamura T, Hikita A and Inoue Y: The roles of TGF- $\beta$ signaling in carcinogenesis and breast cancer metastasis. Breast cancer 19: 118-124, 2012.

11. Bierie B and Moses HL: Tumour microenvironment: TGFbeta: The molecular Jekyll and Hyde of cancer. Nat Rev Cancer 6: 506-620, 2006

12. Akhurst RJ and Derynck R: TGF-beta signaling in cancer-a double-edged sword. Trends Cell Biol 11: S44-S51, 2001.

13. Liu RY, Zeng Y, Lei Z, Wang L, Yang H, Liu Z, Zhao J and Zhang HT: JAK/STAT3 signaling is required for TGF- $\beta$-induced epithelial-mesenchymal transition in lung cancer cells. Int $\mathbf{J}$ Oncol 44: 1643-1651, 2014.

14. Checa M, Hagood JS, Velazquez-Cruz R, Ruiz V, Garcia-De-Alba C, Rangel-Escareño C, Urrea F, Becerril C, Montaño M, García-Trejo S, et al: Cigarette smoke enhances the expression of profibrotic molecules in alveolar epithelial cells. PLoS One 11: e0150383, 2016.

15. Kessenbrock K, Plaks V and Werb Z: Matrix metalloproteinases: Regulators of the tumor microenvironment. Cell 141: 52-67, 2010.

16. Deryugina EI and Quigley JP: Matrix metalloproteinases and tumor metastasis. Cancer Metastasis Rev 25: 9-34, 2006.

17. Kim HS, Shang T, Chen Z, Pflugfelder SC and Li DQ: TGF-betal stimulates production of gelatinase (MMP-9), collagenases (MMP-1, -13) and stromelysins (MMP-3, -10,-11) by human corneal epithelial cells. Exp Eye Res 79: 263-274, 2004.

18. Wirtz HR and Schmidt M: Acute influence of cigarette smoke on secretion of pulmonary surfactant in rat alveolar type II cells in culture. Eur Respir J 9: 24-32, 1996.

19. Fowles J and Dybing E: Application of toxicological risk assessment principles to the chemical constituents of cigarette smoke. Tob Control 12: 424-430, 203.

20. Johnson MD, Schilz J, Djordjevic MV, Rice JR and Shields PG: Evaluation of in vitro assays for assessing the toxicity of cigarette smoke and smokeless tobacco. Cancer Epidemiol Biomarkers Prev 18: 3263-3304, 2009.

21. Sundar IK, Nevid MZ, Friedman AE and Rahman I: Cigarette smoke induces distinct histone modifications in lung cells: Implications for the pathogenesis of COPD and lung cancer. J Proteome Res 13: 982-996, 2014.

22. Momi N, Ponnusamy MP, Kaur S, Rachagani S, Kunigal SS, Chellappan S, Ouellette MM and Batra SK: Nicotine/cigarette smoke promotes metastasis of pancreatic cancer through $\alpha 7 n$ AChR-mediated MUC4 upregulation. Oncogene 32: 1384-1395, 2013

23. Radisky DC, Levy DD, Littlepage LE, Liu H, Nelson CM, Fata JE, Leake D, Godden EL, Albertson DG, Nieto MA, et al: Raclb and reactive oxygen species mediate MMP-3-induced EMT and genomic instability. Nature 436: 123-127, 2005.

24. Egeblad $M$ and Werb $Z$ : New functions for the matrix metalloproteinases in cancer progression. Nat Rev Cancer 2: 161-174, 2002.

25. Mehner C, Miller E, Nassar A, Bamlet WR, Radisky ES and Radisky DC: Tumor cell expression of MMP3 as a prognostic factor for poor survival in pancreatic, pulmonary, and mammary carcinoma. Genes Cancer 6: 480-489, 2015.

26. Jiang YN, Yan HQ, Huang XB, Wang YN, Li Q and Gao FG: Interleukin 6 trigged ataxia-telangiectasia mutated activation facilitates lung cancer metastasis via MMP-3/MMP-13 up-regulation. Oncotarget 6: 40719-40733, 2015. 
27. Costanza B, Umelo IA, Bellier J, Castronovo V and Turtoi A Stromal modulators of TGF- $\beta$ in cancer. J Clin Med 6: pii: E7, 2017.

28. Derynck $R$ and Zhang YE: Smad-dependent and Smad-independent pathways in TGF-beta family signalling. Nature 425: 577-584, 2003

29. Krstic J and Santibanez JF: Transforming growth factor-beta and matrix metalloproteinases: Functional interactions in tumor stroma-infiltrating myeloid cells. ScientificWorldJournal 2014: 521754,2014

30. Badalucco S, Di Buduo CA, Campanelli R, Pallotta I, Catarsi P, Rosti V, Kaplan DL, Barosi G, Massa M and Balduini A: Involvement of TGF $\beta 1$ in autocrine regulation of proplatelet formation in healthy subjects and patients with primary myelofibrosis. Haematologica 98: 514-517, 2013.

31. Tanaka H, Shinto O, Yashiro M, Yamazoe S, Iwauchi T, Muguruma K, Kubo N, Ohira M and Hirakawa K: Transforming growth factor $\beta$ signaling inhibitor, SB-431542, induces maturation of dendritic cells and enhances anti-tumor activity. Oncol Rep 24: 1637-1643, 2010
32. Matsuyama S, Iwadate M, Kondo M, Saitoh M, Hanyu A, Shimizu K, Aburatani H, Mishima HK, Imamura T, Miyazono K and Miyazawa K: SB-431542 and Gleevec inhibit transforming growth factor-beta-induced proliferation of human osteosarcoma cells. Cancer Res 63: 7791-7798, 2003.

33. Xi H, Shuai QG and Shao LL: Involvement of the TGF31/Smad2/MMP3 signaling pathway in SB431542-induced inhibition of cell invasion in multiple myeloma RPMI 8226 cells. Oncol Lett 14: 541-546, 2017.

(i) (9) This work is licensed under a Creative Commons Attribution-NonCommercial-NoDerivatives 4.0 International (CC BY-NC-ND 4.0) License. 